Nisonof, A., Wissler, F. C., Lipmann, L. N., and Woernley, D. L. (1960). Separation of univalent fragments from the divalent rabbit antibody molecule by reduction disulfide bonds. Archives of Biochemistry and Biophysics, 89, 230-244.

Ramos de Almeida, J. M., and Rosado, L. (1972). Rh blood group of grandmother and incidence of erythroblastosis. Archives of Disease in Childhood, 47, 609-612.

Taylor, J. F. (1967). Sensitisation of Rh-negative daughters by their Rh-positive mothers. New England Journal of Medicine, 276, 547-551.

Woodrow, J. C. (1974). Effectiveness of $\mathrm{Rh}$ prophylaxis. Haematologia (Budapest), 8, 281-290.

Correspondence to Dr C. M. Stern, Department of Paediatrics and Neonatal Medicine, Hammersmith Hospital, Du Cane Road, London W12 0HS.

\title{
Fetal growth and parental consanguinity
}

\author{
J. R. SIBERT, MALATI JADHAV, AND S. G. INBARAJ
}

Christian Medical College, Vellore Tamil Nadu, South India

SUMMARY Anthropometric measurements made on 322 newborn infants in South India were related to parental consanguinity. Uncle-niece and firstcousin marriages were common and the average coefficient of inbreeding was as high as 0.0329 . The measurements (weight, length, head circumference, and triceps and subscapular skinfold thicknesses) of the uncle-niece groups (52 infants) were smaller than those of the first-cousin group (61 infants) which in turn were smaller than the nonconsanguineous group (196 infants). Statistical significance $(\mathrm{P}<0 \cdot 01)$ was only recorded between the weights of the three groups (means 2650.4, 2794.1, and $2833.8 \mathrm{~g}$ ) and between the lengths of the uncle-niece group and the nonconsanguineous group (means 46.92 and $47.79 \mathrm{~cm}$ ). There were no social class or residential differences between the groups. We conclude that there are likely to be recessive genes present in the population, slightly retarding fetal growth.

There are probably more consanguineous marriages in South India than in any other large nonisolated population in the world. Uncle-niece and first-cousin marriages are favoured for a variety of cultural reasons, including keeping property in the family. In the course of a study to assess the effect of maternal nutrition on infant anthropometric measurements (Sibert et al., 1978), we thought it valuable to assess the effect of parental consanguinity on fetal growth.

\section{Material and methods}

Mothers and their babies were studied at two hospitals in Vellore, Tamil Nadu, South India: the
Christian Medical College Hospital and the Government Pentland Hospital. All singleton infants over 37 weeks' gestation born on unselected days were studied during the period August to October 1977. As information on gestation was inaccurate in a significant number, all infants were assessed by the method of Parkin et al. (1976). All but 8 of them were $>39$ weeks' gestation. None of the mothers smoked.

Interns from the Child Health Department assisted with Tamil translation. Information was collected on the relationship between the parents. Information was also collected on the social class of the father, whether the parents paid for the care, and whether the family lived in an urban or rural area. Birthweights of the infants were recorded by midwives on beam scales. Anthropometric measurements were made by one of us (J.R.S.) within 36 hours of birth. Crown-to-heel length was measured by Cardiff neonatometer, and occipito-frontal head circumference by paper tape measure. Infant skinfold thickness was measured by a Holtain caliper (reading to $0.1 \mathrm{~mm}$ ) at the left triceps and subscapular sites using the methods of Oakley et al. (1977).

In the course of the study one stillborn child of first-cousin parents with a form of achondrogenesis was noted but not included in the study. One living microcephalic child of uncle-niece parents was included.

\section{Results}

322 infants were studied. The relationship of their parents is shown in Table 1 . Over $39 \%$ of the children had consanguineous parents. The average coefficient of inbreeding was 0.0329 . Of particular note was the 
Table 1 Relationship of the parents of infants

\begin{tabular}{lrll}
\hline & No. & $\begin{array}{l}\text { Proportion of } \\
\text { population } \\
\left(\mathbf{P}_{1}\right)\end{array}$ & $\begin{array}{l}\text { Inbreeding } \\
\text { coefficient } \\
\left(\mathrm{F}_{1}\right)\end{array}$ \\
\hline $\begin{array}{l}\text { Uncle-niece } \\
\text { Cousin }\end{array}$ & 52 & 0.162 & 0.125 \\
$\quad$ First & 61 & 0.189 & 0.0625 \\
$\quad$ First once removed & 5 & 0.016 & 0.0313 \\
Second & 6 & 0.019 & 0.0156 \\
$\quad$ Third & 2 & 0.006 & 0.0039 \\
All consanguineous & 126 & 0.391 & \\
Nonconsanguineous & 196 & 0.608 & \\
\hline
\end{tabular}

Average inbreeding coefficient $\left(\sum P_{1} F_{1}\right)=0.0329$

large percentage $(16 \cdot 2 \%)$ of uncle-niece marriages. There were no significant differences between the nonconsanguineous and consanguineous groups in social class of the father, whether the parents paid for the care, or whether the parents lived in an urban or rural area.

The means and SDs of the anthropometric measurements of the groups of infants are shown in Table 2. The anthropometric measurements (weight, length, head circumference, and triceps and subscapular skinfold thicknesses) of the consanguineous group as a whole were smaller than the nonconsanguineous group. Nevertheless the weight of the infant was the only parameter in which the differences reached significance $(t=2 \cdot 11, P<0.05)$. Looking at the consanguineous group in greater detail the measurements of the uncle-niece group were smaller than the first-cousin group and the measurements of this group, in turn, were smaller than the nonconsanguineous group. Significant differences were only shown between the weight of these groups $(P<0 \cdot 01)$ and between the length of the uncle-niece group compared with the nonconsanguineous group $(\mathrm{P}<0 \cdot 01)$.

\section{Discussion}

Our study shows that consanguinity contributes to interuterine growth retardation. Studies in Vellore (Rao and Inbaraj, 1977) showed small but significant increases in perinatal mortality with consanguinity. Decreased fetal growth may be one of the mechanisms for this.
Previous studies on birthweight and consanguinity have shown similar findings to ours with small but usually significant changes. Morton (1958), studying Japanese infants, found mean birthweights of 3074 and $3046 \mathrm{~g}$ for his unrelated and first-cousin groups. Similar Japanese data were analysed by Slatis and Hoene (1961) and Schork (1964). Fried and Davies (1974), studying the Moroccan-Jewish community in Jerusalem, found the birthweights of infants with uncle-niece parents were lower (mean $3371 \mathrm{~g}$ ) than those of unrelated parents (mean $3469 \mathrm{~g}$ ).

Our work, taken in conjunction with these previous studies, suggests that there are recessive genes with a slightly retarding effect on fetal growth present in the general population. Although the existence of recessive genes causing major effects on growth are well known, there is no evidence that they are widely distributed, at least in South India.

Infectious diseases and malnutrition are the main health problems in South India and the effects of consanguinity are relatively small, taking the population as a whole. Nevertheless we have seen many tragedies in consanguineous marriages with as diverse recessively inherited conditions as thalassaemia, Niemann-Pick disease, and spinal muscular atrophy. We believe that the reduction in the number of consanguineous marriages in South India, particularly those between uncle and niece, will become increasingly important as the burden of infectious disease and malnutrition is brought under control.

We thank the British Paediatric Association and the H. J. Heinz company for funding the fellowship of J.R.S. We also thank Professor S. X. Charles, Head Department of Obstetrics and Gynaecology, Christian Medical College, and Dr K. Kalyaram, District Medical Officer, North Arcot District, Tamil Nadu, for letting us study their patients, and Dr D. P. Davies and Mr R. Newcombe for their help.

\section{References}

Fried, K., and Davies, A. M. (1974). Some effects of the offspring of uncle-niece marriages in the Morrocan Jewish

Table 2 Anthropometric measurements of groups of infants, arranged by consanguinity of the parents

\begin{tabular}{|c|c|c|c|c|c|c|c|c|}
\hline \multirow{2}{*}{$\begin{array}{l}\text { Anthropometric } \\
\text { measurement }\end{array}$} & \multicolumn{2}{|c|}{ Uncle-niece } & \multicolumn{2}{|c|}{ First-cousin } & \multicolumn{2}{|c|}{ All consanguineous $(n=126)$} & \multicolumn{2}{|c|}{ All nonconsanguineous $(n=196)$} \\
\hline & Mean & $S D$ & Mean & $S D$ & Mean & $S D$ & Mean & $S D$ \\
\hline $\begin{array}{l}\text { Weight }(\mathrm{g}) \\
\text { Length }(\mathrm{cm}) \\
\text { Head circumference }(\mathrm{cm}) \\
\text { Triceps skinfold }(\mathrm{mm}) \\
\text { Subscapular skinfold }(\mathrm{mm})\end{array}$ & $\begin{array}{r}2650 \cdot 4 \\
46 \cdot 92 \\
32 \cdot 67 \\
3 \cdot 51 \\
3 \cdot 36\end{array}$ & $\begin{array}{r}371 \cdot 2 \\
2 \cdot 07 \\
1 \cdot 31 \\
0 \cdot 71 \\
0 \cdot 67\end{array}$ & $\begin{array}{r}2794 \cdot 1 \\
47 \cdot 65 \\
33 \cdot 42 \\
3 \cdot 55 \\
3.46\end{array}$ & $\begin{array}{r}498 \cdot 2 \\
2 \cdot 43 \\
1 \cdot 51 \\
0 \cdot 73 \\
0 \cdot 65\end{array}$ & $\begin{array}{r}2731 \cdot \\
47 \cdot 36 \\
33 \cdot 10 \\
3 \cdot 57 \\
3 \cdot 42\end{array}$ & $\begin{array}{r}435 \cdot 1 \\
2 \cdot 22 \\
1 \cdot 43 \\
0 \cdot 72 \\
0 \cdot 66\end{array}$ & $\begin{array}{r}2833 \cdot 8 \\
47 \cdot 79 \\
33 \cdot 35 \\
3 \cdot 58 \\
3 \cdot 51\end{array}$ & $\begin{array}{r}406 \cdot 9 \\
2 \cdot 16 \\
1 \cdot 60 \\
0 \cdot 70 \\
0 \cdot 74\end{array}$ \\
\hline
\end{tabular}


community in Jerusalem. American Journal of Human Genetics, 26, 65-72.

Morton, N. E. (1958). Empirical risks in consanguineous marriages: birthweight, gestation time, and measurements of infants. American Journal of Human Genetics, 10, 344-349.

Oakley, J. R., Parsons, R. J., and Whitelaw, A. G. L. (1977). Standards for skinfold thickness in British newborn infants. Archives of Disease in Childhood, 52, 287-290.

Parkin, J. M., Hey, E. N., and Clowes, J. S. (1976). Rapid assessment of gestational age at birth. Archives of Disease in Childhood, 51, 259-263.

Rao, P. S. S., and Inbaraj, S. G. (1977). Inbreeding effects on human reproduction in Tamil Nadu of South India. Annals of Human Genetics, 41, 87-99.
Schork, M. A. (1964). The effects of inbreeding on growth. American Journal of Human Genetics, 16, 292-299.

Sibert, J. R., Jadhav, M., and Inbaraj, S. G. (1978). Maternal and fetal nutrition in south India. British Medical Journal, 1, 1517-1518.

Slatis, H. M., and Hoene, R. E. (1961). The effect of consangunity on the distribution of continuously variable characteristics. American Journal of Human Genetics, 13, 28-31.

Correspondence to Dr J. R. Sibert, Department of Paediatrics, Llandough Hospital, Penarth, South Glamorgan CF6 1QD. 